\title{
ISOLASI DAN SELEKSI MIKROBA POTENSIAL SEBAGAI AKTIVATOR PENGOMPOSAN UNTUK MENDEKOMPOSISI LIMBAH KULIT MANGIUM
}

\section{(Isolation and Selection of Potential Microbes as Composting Activator in Decomposing Mangium Bark)}

\author{
Oleh/By :
}

\section{Gusmailina}

Diterima 30 Januari 2009, disetujui 16 Juli 2009

\begin{abstract}
Wood bark of particular plants reveals potential wastes reusable effectively through proper treatment. Several species of wood bark can inflict toxicity on the growth of plant roots, thereby necessitating preliminary treatment prior to its uses. One of the manners can proceed through the composting process, whereby it necessitates microorganisms as activator to degrade wood bark in relatively short duration. In this way, the wood bark decomposed into compost can further be used as the growth media forplants in the nursery as well as in the field.

This research aimed to look microbes potentially effective that would be used as activator in the composting of Acacia mangium bark wastes through tha stages of consecutively exploration, isolation, and selection of microbes already existed in those barks. Microbe selection and isolation was performed on various natural habitats, involving mangium bark. piles situated at PT TEL Pulp and Paper (South Sumatera) and PT IKPP, Perawang (Riau).

Results signified that from those two exploration locations (PT TEL Pulp and Paper and PT IKPP) were acquired 46 microbe isolates comprising 23 fungi isolates and 23 bacteria isolates. As many as 30 isolats (i.e. 15 fungi and 15 bacteria isolates) were originated from PT TEL Pulp and Paper, and 16 isolats (8 fungi isolates and 8 bacteria isolates) from PT IKPP. Almost all the fungi isolates afforded to degrade lignin and cellulose at medium to fast rate. Meanwhile, bacteria isolates as acquired served only as decaying agent. Among all the acquire isolates were selected 7 fungi isolates presumed potentially effective to represent those locations.
\end{abstract}

Keywords: Wood bark wastes, mangium, decomposing, composting, microbe, isolats

\begin{abstract}
ABSTRAK
Kulit kayu merupakan limbah organik yang dapat dimanfaatkan kembali secara efektif dengan memberi perlakuan yang tepat. Beberapa jenis kulit kayu dapat menyebabkan racun bagi pertumbuhan akar tanaman, sehingga harus diberi perlakuan terlebih dahulu sebelum digunakan. Salah cara adalah melalui pengomposan. Dalam proses tersebut diperlukan mikroorganisme sebagai aktivator yang berperan mendegradasi kulit kayu dalam waktu singkat. Kulit kayu yang telah terdekomposisi dan menjadi kompos selanjutnya dapat digunakan sebagai media tumbuh tanaman baik di persemaian mapun di lapangan.

Penelitian bertujuan mencermati mikroba potensial efektif digunakan sebagai aktivator pada pengomposan limbah kulit Acacia mangium, meliputi tahapan eksplorasi, isolasi, dan seleksi mikroba
\end{abstract}


yang terdapat pada limbah kulit tersebut. Isolasi mikroba dilakukan pada berbagai tempat habitat alami yaitu pada areal tumpukan kulit mangium di PT. TEL (Tanjung Enim Lestari) Pulp \& Paper (Sumatera Selatan) dan PT. IKPP (Indah Kiat Pulp \& Paper), Perawang (Riau).

Hasil menunjukkan bahwa dari dua lokasi eksplorasi yang telah dilakukan, diperoleh 46 isolat mikroba yang terdiri dari 23 isolat fungi dan 23 isolat bakteri. Sebanyak 30 isolat (15 isolat fungi \& 15 isolat bakteri) asal PT. TEL Palembang, dan 16 isolat (8 isolat fungi \& 8 isolat bakteri) asal PT. IKPP, Perawang, Pekanbaru. Hampir semua isolat fungi positif mempunyai kemampuan menguraikan lignin dan selulosa dengan kecepatan sedang hingga cepat, sedangkan isolat bakteri yang diperoleh ternyata hanya bersifat pembusuk. Diantara semua isolat yang diperoleh, terpilih 7 isolat fungi yang diperkirakan potensial efektif mewakili ke dua lokasi.

Kata kunci : Limbah kulit kayu, mangium, pelapukan, pengomposan, mikroba, isolat.

\section{PENDAHULUAN}

Kulit kayu merupakan limbah organik potensial, dengan sedikit perlakuan dapat dimanfaatkan kembali sebagai media pada persemaian atau kembali ke lahan sebagai upaya untuk mengembalikan sebagian bahan terangkut pada saat panen. Kelemahan dari kulit kayu ini mempunyai nisbah karbon-nitrogen $(\mathrm{C} / \mathrm{N})$ sangat tinggi yang menyebabkan defisiensi unsur hara pada bibit tanaman hutan apabila tidak diberi perlakuan secara tepat. (Brundrett $e t$ al., 1996).

Sekitar 80\% (15,18 ton/ha) dari kulit Acacia mangium yang terangkut ke industri pulp kertas, hanya 20\% yang dapat dimanfaatkan untuk bahan bakar boiler. Sisanya menjadi polutan yang potensial mencemari lingkungan, terutama perairan sekitarnya (Gusmailina, et al., 2002). Untuk mencegah timbulnya masalah bagi industri pulp, membakar adalah salah satu jalan yang ditempuh selama ini untuk menyelesaikan masalah limbah kulit. Padahal membakar menyalahi kaidah dan konsep ekologis yang lestari, karena material organik yang terangkut dari lahan pada saat panen dikembalikan lagi ke lahan tersebut dalam bentuk bahan siap pakai untuk menjaga stabilitas bahan organik tanah. Hal ini perlu diperhatikan agar produktivitas lahan dan tanaman tetap terjaga, sehingga industripun terjaga kesinambungan produksinya.

Beberapa jenis kulit kayu mengandung bahan ekstraktif tertentu yang dapat menyebabkan racun bagi pertumbuhan akar tanaman, sehingga harus diberi perlakuan terlebih dahulu sebelum digunakan. Cara terbaik untuk mengatasi kelemahan tersebut adalah melakukan proses pengomposan melalui pencampuran dengan beberapa bahan organik lainnya, sehingga kekurangan unsur hara essensial dapat terpenuhi. Dalam proses pengomposan diperlukan mikroorganisme sebagai aktivator yang berperan untuk mendegradasi kulit kayu dalam waktu singkat. Kulit kayu yang telah terdekomposisi dan menjadi kompos, selanjutnya dapat digunakan sebagai media tumbuh tanaman baik di persemaian mapun di lapangan.

Terkait dengan uraian tersebut, telah dilakukan penelitian dengan tujuan mencari mikroba potensial efektif berasal dari limbah kulit kayu mangium. Ini merupakan penelitian awal yang nantinya akan digunakan sebagai aktivator pada pengomposan limbah kulit Acacia mangium. Kegiatan penelitian tersebut meliputi eksplorasi, isolasi, dan seleksi mikroba yang terdapat pada tumpukan limbah kulit mangium. Isolasi mikroba dilakukan pada berbagai 
tempat habitat alami yaitu, pada areal tumpukan kulit mangium di PT. TEL (Tanjung Enim Lestari) Pulp \& Paper (Sumatera selatan) dan PT. IKPP (Indah Kiat Pulp \& Paper), Perawang (Riau). Kegiatan yang hampir sama juga dilakukan oleh Djarwanto, Suprapti dan Martono (2008), tetapi aktivitas yang dilakukan lebih difokuskan pada teknik koleksi fungi pelapuk pada areal HTI pulp.

\section{BAHAN DAN METODE}

\section{A. Bahan dan Alat}

1. Bahan utama yang digunakan antara lain: serbuk kulit kayu mangum dengan ukuran 40150 mesh. Bahan diambil dari habitat alami pada tumpukan serbuk dan kulit kayu mangium di area PT. TEL Pulp \& Paper, Muara Enim Palembang (Sumatera Selatan) dan PT. IKPP (Indah Kiat Pulp \& Paper) Perawang (Riau). Di PT. TEL contoh diambil pada berbagai kondisi tumpukan limbah mulai yang berumur 3 bulan hingga tumpukan umur 3 tahun. Di PT. IKPP, bahan diambil di areal komposting secara alami mulai umur 0,5 bulan hingga umur 6 bulan.

2. Berbagai bahan kimia dan mikrobiologis lainnya seperti RBB (reamazol brilliant blue), selopan, medium agar, medium MMN (modified melin norkerans), medium Pachelewski, $\mathrm{H}_{2} \mathrm{O}_{2}$ $5 \%$, sodium hipoklorit 5\%, asam laktat, triphan blue, kertas lakmus ( $\mathrm{pH}$ indikator), kertas saring, cotton blue, bacto agar, guaiacol, alcohol, potato dextrose agar (PDA), ethanol, glycerol, basanud $3 G$, triphan blue, dektrose, potasium bydroksida pellets, serta bahan penunjang lainnya seperti air suling, kantong plastik dan lain-lain.

3. Alat yang dipakai antara lain autoclave, laminar, pisau, pinset, ose, cawan petri, bak plastik, kaliper, meteran, preparat dan cover glass, timbangan analitik, oven, $\mathrm{pH}$ meter, planimetri, lampu spiritus, dan peralatan gelas seperti: tabung reaksi, gelas piala, erlenmeyer, dan lainlain.

\section{B. Metode}

1. Tahap 1 (Eksplorasi, isolasi dan seleksi)

Kegiatan eksplorasi dilakukan pada habitat alami pada tumpukan serbuk dan kulit kayu mangium di area PT. TEL Pulp \& Paper, Muara Enim Palembang (Sumsel) dan PT. IKPP (Indah Kiat Pulp \& Paper) Perawang, Pekanbaru (Riau). Eksplorasi di beberapa tempat yang diperkirakan mengandung mikroba dekomposer yang ditandai dengan pembusukan atau pelapukan dari limbah kulit tersebut. Eksplorasi ada yang di bagian permukaan, tengah dan bagian bawah tumpukan kulit pada beberapa tingkat umur tumpukan dengan indikasi melalui warna spora yang terbentuk. Ada kelompok fungi yang menunjukkan spora dengan warna kemerahan, kebiruan, kekuningan dan keputihan. Tetapi warna tersebut tidak menyolok, kecuali jika dilihat dan diperhatikan secara teliti. Kondisi inipun jarang dijumpai karena eksplorasi dilakukan pada musim kemarau.

Hasil eksplorasi dibawa ke laboratrium, dicuci, dipisahkan lalu diencerkan secara bertingkat untuk ditumbuhkan pada media yang sudah disediakan (metode Nishida et al., 1988). Kemudian dilakukan isolasi dan screening dalam beberapa tingkat untuk mendapatkan 
isolat murni. Masing-masing sampel juga dianalisis kandungan $\mathrm{C}$ organik, dan $\mathrm{N}$ untuk mengetahui tingkat pembusukan/pelapukan yang terjadi melalui nilai $\mathrm{C} / \mathrm{N}$ yang diperoleh. Pada tahap akhir pengujian, media dicampur dengan serbuk kulit Acacia mangium, sehingga diperoleh isolat mikroba yang diperkirakan berpotensi sebagai dekomposer kulit $A$. mangium. Pengujian dilakukan beberapa tahap dengan 4 kali ulangan untuk mendapatkan hasil yang tepat.

2. Tahap 2 (uji sellulolitik dan lignolitik)

a. Kemampuan selulolitik diuji secara kualitatif dengan mengikuti prosedur Poincelot dan Day (1972) dan Moore et al. (1979) dengan melihat pelepasan pewarna RBB dari selopan. Selopan yang telah diberi RBB digunakan untuk mengetahui kemampuan isolat dalam mengurai selulosa, yang diletakkan di atas medium agar. Isolat yang telah diinokulasi diinkubasi pada suhu kamar dan suhu $37^{\circ} \mathrm{C}$. Kemampuan selulolitik diamati setiap hari selama seminggu dengan kriteria adanya pelepasan pewarna RBB dari selopan ke dalam media dan/atau hilangnya pewarna RBB dari selopan.

b. Kemampuan isolat dalam mengurai lignin diuji mengikuti metode Nishida et al. (1988) yang telah dimodifikasi yaitu isolat ditumbuhkan pada medium yang ditambah dengan serbuk kulit kayu mangium dengan ukuran 150 mesh dan $0.025 \mathrm{ml}$ guaiakol. Kemudian diinkubasi pada suhu kamar $37^{\circ} \mathrm{C}$ selama 7 hari. Pada hari ke 7 diamati intensitas warna cokelat dari daerah cincin (terang, normal, gelap) yang terbentuk disekitar koloni pada medium, lalu diukur luasnya dengan menggunakan planimetri. Warna cokelat gelap dengan luas lebih dari $5 \mathrm{~cm}^{2}$ yang terbentuk digunakan untuk menduga besarnya kemampuan lignolitik dari isolat tersebut. Kriteria ini didasarkan atas asumsi bahwa makin besar kemampuan lignolitik dari suatu isolat, maka makin banyak lignin yang didegradasi atau semakin banyak fenol yang terbentuk sehingga makin gelap atau luas daerah cincin cokelat yang terbentuk (Rayner dan Body, 1988).

3. Parameter yang diukur

a. Lapangan

Parameter yang diukur selain visualisasi mikroba yang berkembang pada tumpukan limbah kulit mangium di lapangan, juga kondisi keasaman $(\mathrm{pH})$, kelembaban, dimana dilakukan eksplorasi mikroba.

b. Laboratorium

Analisis karbon-nitrogen $(\mathrm{C} / \mathrm{N})$ rasio bahan. Pengukuran intensitas warna cokelat dari daerah cincin (terang, gelap, normal) yang terbentuk di sekitar koloni pertumbuhan mikroba (menurut Rayner dan Body, 1988).

\section{Analisis Data}

1. Isolasi dan seleksi diuji secara kualitatif untuk mengetahui mikroba yang diperoleh termasuk fungi atau bakteri serta dengan mengikuti prosedur Poincelot dan Day (1972) dan Moore et al., (1979) dengan melihat pelepasan pewarna RBB dari selopan

2. Analisis sifat dan karakterisitik bahan serbuk dan kulit kayu meliputi nisbah $\mathrm{C} / \mathrm{N}$ limbah kulit mangium 
3. Data yang diperoleh selanjutnya dianalisis untuk mengetahui isolat mikroba yang diperkirakan berpotensi sebagai dekomposer. Penetapan isolat terpilih berdasarkan pengamatan parameter pertumbuhan koloni mikroba pada saat uji lignolitik, melalui luas area cincin yang berwarna cokelat yang diukur dengan menggunakan planimetri (menurut Rayner dan Body, 1988).

4. Tulisan ini merupakan hasil penelitian tahun pertama dari 5 tahun rencana penelitian. Identifikasi mikroba akan dilakukan pada akhir penelitian jika sudah diketahui mikroba yang potensial efektif sebagai dekomposer.

\section{HASIL DAN PEMBAHASAN}

\section{A. Eksplorasi Mikroba}

Eksplorasi yang dilakukan di beberapa tempat yang mengandung mikroba dapat dilihat pada Tabel 1 dan 2 meliputi kondisi keasaman/pH dan nisbah $\mathrm{C} / \mathrm{N}$ dari masing-masing sampel yang berasal dari lokasi eksplorasi yaitu PT. TEL dan PT. IKPP. Pada Tabel 3 dan 4 dapat diketahui hasil isolasi dan seleksi mikroba asal PT. TEL dan PT. IKPP berdasarkan lokasi eksplorasi. Sementara pada Gambar 1 dapat dilihat sebagian contoh isolat yang berasal dari PT. TEL mencakup golongan bakteri (A) dan golongan fungi (B).

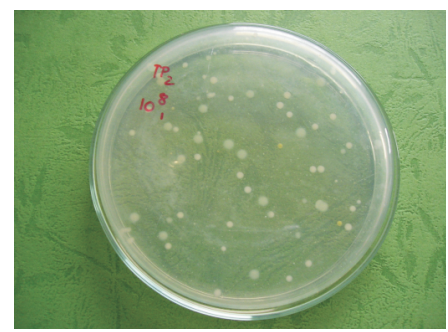

A

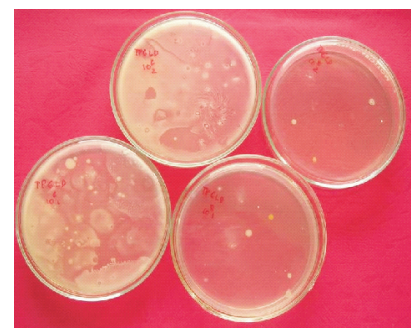

A

Gambar1. Contoh sebagian isolat golongan bakteri (A) dan fungi (B).

Figure 1. Samples revealing part of isolats with regard to bacteria group (A) and fungigroup $(B)$ 
Tabel1. Hasil analisis sifat dan karakteristik bahan penelitian berdasarkan lokasi eksplorasi mikroba di PT. TEL, Sumatera Selatan

Table 2. Results of analysis on properties and characteristics of research materials that correspond to the site of microbe exploration at PT. TEL (South Sumatera)

\begin{tabular}{|c|c|c|c|c|c|c|c|c|}
\hline No & $\begin{array}{c}\text { Kode contoh } \\
\text { (Sample code) }\end{array}$ & \multicolumn{2}{|c|}{$\begin{array}{l}\text { Pengenceran } \\
\text { (Dilution) }\end{array}$} & Media & $\mathrm{pH}$ & $\begin{array}{c}\text { C Organik } \\
\text { (Organic) }\end{array}$ & N-Kjeldahl & $\begin{array}{l}\mathrm{C} / \mathrm{N} \\
\text { ratio }\end{array}$ \\
\hline 1 & LFK & $\begin{array}{l}10^{6} \\
10^{4}\end{array}$ & $\begin{array}{l}10^{8} \\
10^{6}\end{array}$ & $\begin{array}{l}\text { NA } \\
\text { MEA }\end{array}$ & 5,1 & 42,96 & 0,92 & 46,48 \\
\hline 2 & LFB & $\begin{array}{l}10^{6} \\
10^{4}\end{array}$ & $\begin{array}{l}10^{8} \\
10^{6}\end{array}$ & $\begin{array}{l}\text { NA } \\
\text { MEA }\end{array}$ & 6,0 & 27,69 & 1,22 & 22,61 \\
\hline 3 & TP2 & $\begin{array}{l}10^{6} \\
10^{4}\end{array}$ & $\begin{array}{l}10^{8} \\
10^{6}\end{array}$ & $\begin{array}{l}\text { NA } \\
\text { MEA }\end{array}$ & 5,2 & 33,58 & 0,93 & 35,98 \\
\hline 4 & TP3 & $\begin{array}{l}10^{6} \\
10^{4}\end{array}$ & $\begin{array}{l}10^{8} \\
10^{6}\end{array}$ & $\begin{array}{l}\text { NA } \\
\text { MEA }\end{array}$ & 5,2 & 40,61 & 0,83 & 33,36 \\
\hline 5 & TP4 & $\begin{array}{l}10^{6} \\
10^{4}\end{array}$ & $\begin{array}{c}10^{8} \\
10^{6}\end{array}$ & $\begin{array}{l}\text { NA } \\
\text { MEA }\end{array}$ & 5,1 & 42,81 & 1,01 & 42,30 \\
\hline 6 & TP5 & $\begin{array}{l}10^{6} \\
10^{4}\end{array}$ & $\begin{array}{l}10^{8} \\
10^{6}\end{array}$ & $\begin{array}{l}\text { NA } \\
\text { MEA }\end{array}$ & 6,7 & 14,70 & 1,34 & 10,99 \\
\hline 7 & TPDA & $\begin{array}{l}10^{6} \\
10^{4}\end{array}$ & $\begin{array}{l}10^{8} \\
10^{6}\end{array}$ & $\begin{array}{l}\text { NA } \\
\text { MEA }\end{array}$ & 6,3 & 37 & 1,30 & 28,46 \\
\hline 8 & TP6LD & $\begin{array}{l}10^{6} \\
10^{4}\end{array}$ & $\begin{array}{l}10^{8} \\
10^{6}\end{array}$ & $\begin{array}{l}\text { NA } \\
\text { MEA }\end{array}$ & 5,0 & 32,48 & 1,06 & 30,63 \\
\hline 9 & TP6LL & $\begin{array}{l}10^{6} \\
10^{4}\end{array}$ & $\begin{array}{l}10^{8} \\
10^{6}\end{array}$ & $\begin{array}{l}\text { NA } \\
\text { MEA }\end{array}$ & 5,0 & 37 & 0,88 & 42,02 \\
\hline 10 & TP6A & $\begin{array}{l}10^{6} \\
10^{4}\end{array}$ & $\begin{array}{l}10^{8} \\
10^{6}\end{array}$ & $\begin{array}{l}\text { NA } \\
\text { MEA }\end{array}$ & 5,1 & 40,02 & 1,25 & 32,13 \\
\hline 11 & SB1 & $\begin{array}{l}10^{6} \\
10^{4}\end{array}$ & $\begin{array}{l}10^{8} \\
10^{6}\end{array}$ & $\begin{array}{l}\text { NA } \\
\text { MEA }\end{array}$ & 5,1 & 45,58 & 1,18 & 38,69 \\
\hline 12 & SBKT & $\begin{array}{l}10^{6} \\
10^{4}\end{array}$ & $\begin{array}{l}10^{8} \\
10^{6}\end{array}$ & $\begin{array}{l}\text { NA } \\
\text { MEA }\end{array}$ & 6,0 & 40,26 & 1,89 & 21,29 \\
\hline 13 & SBKTB & $\begin{array}{l}10^{6} \\
10^{4}\end{array}$ & $\begin{array}{l}10^{8} \\
10^{6}\end{array}$ & $\begin{array}{l}\text { NA } \\
\text { MEA }\end{array}$ & 5,1 & 38,38 & 0,97 & 39,57 \\
\hline 14 & SBKAT & $\begin{array}{l}10^{6} \\
10^{4} \\
\end{array}$ & $\begin{array}{c}10^{8} \\
10^{6}\end{array}$ & $\begin{array}{l}\text { NA } \\
\text { MEA }\end{array}$ & 5,9 & 41,01 & 0,62 & 26,41 \\
\hline 15 & SBM & $\begin{array}{l}10^{6} \\
10^{4}\end{array}$ & $\begin{array}{l}10^{8} \\
10^{6}\end{array}$ & $\begin{array}{l}\text { NA } \\
\text { MEA }\end{array}$ & 4,6 & 44,93 & 0,77 & 58,15 \\
\hline
\end{tabular}

Keterangan (Remarks) :

LFK : Land fillkering (wet landfill)

LFB : Landfil agak basah (ratherwet landfill)

TP2 : Tempat pembuangan limbah serbuk dan kulit di pabrik umur 2 bulan (Discarding location for waste of sawdust and wood bark in the factory, at 2 month duration)

TP3 : Tempat pembuangan limbah serbuk dan kulit di pabrik umur 3 bulan (Discarding location for waste of sawdust and wood bark in the factory, at 3 month duration) 
TP4 : Tempat pembuangan limbah serbuk dan kulit di pabrik umur 4 bulan (Discarding location for waste of sawdust and wood bark in the factory, at 4 month duration)

TP5 : Tempat pembuangan limbah serbuk dan kulit di pabrik umur 5 bulan (Discarding location for waste of sawdust and wood bark in the factory, at 5 month duration)

TP6LD : Tempat pembuangan limbah serbuk dan kulit di pabrik umur 6 bulan, lapisan dalam (Discarding location for waste of sawdust and wood bark in the factory, at 6 month duration, inner layer)

TP6LL : Tempat pembuangan limbah serbuk dan kulit di pabrik umur 6 bulan, lapisan luar (Discarding location for waste of sawdust and wood bark in the factory, at 6 month duration, outer layer)

TP6A : Tempat pembuangan limbah serbuk dan kulit di pabrik umur 6 bulan, bagian atas (Discarding location for waste of sawdust and wood bark in the factory, at 6 month duration, upperportion

TPDA : Tempat pembuangan limbah serbuk dan kulit dekat air (Discarding location for waste of sawdust and wood bark in the factory, near the water)

SB1 : Suban jeriji 1/kondisi basah (wet condition)

SBKT : Suban jeriji 2/kondisi basah (wetcondition)

SBKTB : Suban jeriji 3/kondisi basah (wet condition)

SBKAT : Suban jeriji 4/kondisi basah (wet condition)

SBM : Suban jeriji 5/kondisi basah (wet condition)

NA : Natrium Agar (Sodium agar)

MEA : Malt Extract Agar

Tabe12. Hasil analisis sifat dan karakteristik bahan penelitian berdasarkan lokasi eksplorasi mikroba di PT. IKPP, Pekanbaru (Riau)

Table2. Results of analysis on properties and characteristics of research materials that correspond to the site of microbe exploration at PT. IKPP, Pekanbaru (Riau)

\begin{tabular}{|c|c|c|c|c|c|c|c|c|c|}
\hline No & $\begin{array}{l}\text { Kode } \\
\text { contoh } \\
\text { (Sample } \\
\text { code) }\end{array}$ & $\begin{array}{c}\text { Lokasi eksplorasi } \\
\text { (Exploration } \\
\text { location) }\end{array}$ & \multicolumn{2}{|c|}{$\begin{array}{c}\text { Pengenceran } \\
\text { (Dillution) }\end{array}$} & Media & $\mathrm{pH}$ & $\begin{array}{l}\text { C Organik } \\
\text { (C Organic) }\end{array}$ & $\begin{array}{c}\mathrm{N}- \\
\text { Kjeldahl }\end{array}$ & $\begin{array}{l}\mathrm{C} / \mathrm{N} \\
\text { ratio }\end{array}$ \\
\hline 1 & $\mathrm{~A}$ & $\begin{array}{l}\text { Tumpukan } \\
\text { awal } \\
\text { composting } \\
\text { (early composted } \\
\text { pile) }\end{array}$ & $\begin{array}{l}10^{6} \\
10^{4}\end{array}$ & $\begin{array}{l}10^{8} \\
10^{6}\end{array}$ & $\begin{array}{c}\text { NA } \\
\text { MEA }\end{array}$ & 4,8 & 56,58 & 0,82 & 69 \\
\hline 2 & B & $\begin{array}{l}\text { Tumpukan } \\
\text { komposting } 0,5 \\
\text { bulan } \\
\text { (Composted pile } \\
\text { with 0,5 month } \\
\text { duration) }\end{array}$ & $\begin{array}{l}10^{6} \\
10^{4}\end{array}$ & $\begin{array}{l}10^{8} \\
10^{6}\end{array}$ & $\begin{array}{c}\text { NA } \\
\text { MEA }\end{array}$ & 5,6 & 68,13 & 1,74 & 39 \\
\hline 3 & $\mathrm{C}$ & $\begin{array}{l}\text { Tumpukan } \\
\text { komposting } 1 \\
\text { bulan } \\
\text { (Composted pile } \\
\text { with } 1 \text { month } \\
\text { duration) }\end{array}$ & $\begin{array}{l}10^{6} \\
10^{4}\end{array}$ & $\begin{array}{c}10^{8} \\
10^{6}\end{array}$ & $\begin{array}{c}\text { NA } \\
\text { MEA }\end{array}$ & 5,4 & 56,88 & 1,74 & 33 \\
\hline
\end{tabular}


Tabel 2. (Lanjutan)

Table2. (Continued)

\begin{tabular}{|c|c|c|c|c|c|c|c|c|c|}
\hline No & $\begin{array}{l}\text { Kode } \\
\text { contoh } \\
\text { (Sample } \\
\text { code) }\end{array}$ & $\begin{array}{c}\text { Lokasi eksplorasi } \\
\text { (Exploration } \\
\text { location) }\end{array}$ & \multicolumn{2}{|c|}{$\begin{array}{l}\text { Pengenceran } \\
\text { (Dillution) }\end{array}$} & Media & $\mathrm{pH}$ & $\begin{array}{l}\text { C Organik } \\
\text { (C Organic) }\end{array}$ & $\begin{array}{c}\mathrm{N}- \\
\text { Kjeldahl }\end{array}$ & $\begin{array}{l}\mathrm{C} / \mathrm{N} \\
\text { ratio }\end{array}$ \\
\hline 4 & $\mathrm{D}$ & $\begin{array}{l}\text { Tumpukan } \\
\text { komposting } 2 \\
\text { bulan } \\
\text { (Composted pile } \\
\text { with } 2 \text { month } \\
\text { duration) }\end{array}$ & $\begin{array}{l}10^{6} \\
10^{4}\end{array}$ & $\begin{array}{l}10^{8} \\
10^{6}\end{array}$ & $\begin{array}{c}\text { NA } \\
\text { MEA }\end{array}$ & 5,0 & 54,32 & 1,06 & 51 \\
\hline 5 & $\mathrm{E}$ & $\begin{array}{l}\text { Tumpukan } \\
\text { komposting } 3 \\
\text { bulan } \\
\text { (Composted pile } \\
\text { with } 3 \text { month } \\
\text { duration) }\end{array}$ & $\begin{array}{l}10^{6} \\
10^{4}\end{array}$ & $\begin{array}{l}10^{8} \\
10^{6}\end{array}$ & $\begin{array}{c}\mathrm{NA} \\
\mathrm{MEA}\end{array}$ & 4,6 & 59,25 & 0,92 & 64 \\
\hline 6 & F & $\begin{array}{l}\text { Tumpukan } \\
\text { komposting } 4 \\
\text { bulan } \\
\text { (Composted pile } \\
\text { with } 4 \text { month } \\
\text { duration) }\end{array}$ & $\begin{array}{l}10^{6} \\
10^{4}\end{array}$ & $\begin{array}{l}10^{8} \\
10^{6}\end{array}$ & $\begin{array}{c}\text { NA } \\
\text { MEA }\end{array}$ & 5,5 & 45,26 & 1,52 & 30 \\
\hline 7 & G & $\begin{array}{l}\text { Tumpukan } \\
\text { komposting } 5 \\
\text { bulan } \\
\text { (Composted pile } \\
\text { with } 5 \text { month } \\
\text { duration) }\end{array}$ & $\begin{array}{l}10^{6} \\
10^{4}\end{array}$ & $\begin{array}{l}10^{8} \\
10^{6}\end{array}$ & $\begin{array}{c}\text { NA } \\
\text { MEA }\end{array}$ & 5,8 & 54,82 & 2,06 & 27 \\
\hline 8 & $\mathrm{H}$ & $\begin{array}{l}\text { Tumpukan } \\
\text { komposting } 6 \\
\text { bulan } \\
\text { (Composted pile } \\
\text { with } 6 \text { month } \\
\text { duration) }\end{array}$ & $\begin{array}{l}10^{6} \\
10^{4}\end{array}$ & $\begin{array}{l}10^{8} \\
10^{6}\end{array}$ & $\begin{array}{c}\text { NA } \\
\text { MEA }\end{array}$ & 5,7 & 42,40 & 1,46 & 29 \\
\hline
\end{tabular}

Keterangan (Remarks) : Proses pengomposan terjadi karena aktifitas mikroba alami (The composting process took place due to the activity of natural microbes) 
Berdasarkan Tabel 1 dan 2 dapat diketahui bahwa dari dua lokasi pengambilan sampel yang telah dilakukan, diperoleh 23 isolat mikroba, masing-masing 15 isolat dari TEL, 8 isolat dari PT. IKPP. Kondisi pH sewaktu pengambilan sampel di lokasi TEL berkisar antara 4,6 sampai 6,7, dengan rata-rata 5,4. Kondisi ini termasuk rendah yang menunjukkan bahwa sampel yang diambil masih dalam proses penghancuran/pembusukan secara alami. Dari sekian sampel yang diperoleh hanya satu sampel yang mempunyai kondisi $\mathrm{pH}$ mendekati normal yaitu 6,7. Kondisi ini menunjukkan bahwa sampel yang diambil telah mengalami proses penghancuran secara alami yaitu pada tumpukan limbah yang telah berumur 5 bulan. Berbeda dengan tumpukan limbah yang telah berumur 6 bulan, tetapi memiliki $\mathrm{pH}$ yang lebih rendah dibanding dengan kondisi tumpukan limbah umur 5 bulan. Oleh sebab itu dalam penelitian ini kondisi $\mathrm{pH}$ yang tercatat belum menunjukkan standar untuk menentukan kondisi tingkat penghancuran limbah secara alami, karena tingkat pembusukan/ penghancuran/penguraian limbah secara alami yang terjadi dalam satu tumpukan tidak sama. Namun demikian walaupun nilai $\mathrm{pH}$ yang dicatat hanya merupakan faktor penunjang, dan akan memberikan gambaran bahwa di tempat tersebut telah terjadi proses penghancuran secara alami, berarti pada tempat tersebut terdapat mikroba pengurai. Hal yang sama juga diketahui bahwa $\mathrm{pH}$ yang tercatat dari sampel di PT. IKPP berkisar antara 4,6 - 5,8. Kondisi ini menunjukkan bahwa substrat dimana eksplorasi mikroba dilakukan telah mengalami penguraian. Sampel yang diambil pada tumpukan proses pengomposan umur 5 dan 6 bulan mempunyai nilai $\mathrm{pH}$ terbesar yaitu 5,7 dan 5,8 yang artinya mendekati $\mathrm{pH}$ normal dan kemungkinan proses penguraian hampir selesai.

Indikasi lain secara visual dalam pengambilan sampel adalah warna yang ditunjukkan oleh spora dari mikroba (fungi). Walaupun warna yang ditunjukkan tidak begitu jelas, namun jika diperhatikan secara seksama warna tersebut akan terlihat pada beberapa tempat. Pelaksanaan eksplorasi agak kurang tepat, karena dilakukan pada saat musim kemarau, sehingga menghambat pertumbuhan mikroba, terutama golongan fungi akibat kelembaban yang sangat rendah. Selama eksplorasi tidak pernah dijumpai fungi tingkat tinggi. Fungi ini sangat mudah dikenal melalui keberadaan tubuh buahnya.

Eksplorasi mikroba di PT. IKPP, lebih terfokus. Pengambilan sampel dilakukan pada area komposting yang berjarak sekitar $3 \mathrm{~km}$ dari pabrik. Sejak 2 tahun terakhir, PT. IKPP telah mencoba mengolah berbagai jenis limbah padat pabrik menjadi kompos yaitu berupa campuran limbah kulit, serbuk kayu, sludge padat dan sludge lumpur, abu sisa pembakaran boiler, dan gambut. Teknik pengomposan dilakukan secara aerobik konvensional, ditumpuk memanjang, terbuka dan tanpa menggunakan aktivator atau mikroba tertentu, tetapi hanya mengandalkan mikroba yang ada di alam secara alamiah, sehingga membutuhkan waktu yang lama yaitu 6 bulan. Setiap hari dibolak-balik dengan menggunakan excavator. Sampel diambil di setiap tumpukan komposting mulai dari tumpukan yang berumur 1 bulan, seterusnya hingga umur 6 bulan. Namun dari analisis sementara menunjukkan bahwa kompos yang dihasilkan kurang sempurna, karena proses yang terjadi bukan proses pengomposan, tetapi lebih cenderung kepada proses pembusukan dengan mengandalkan iklim dan cuaca setempat. Kemungkinan hal ini yang menjadi penyebab mengapa dari hasil isolasi mikroba yang diperoleh (Tabel 4), jumlah bakteri lebih banyak dari pada fungi.

Gambar 2 bertujuan untuk mengetahui jumlah perolehan mikroba berdasarkan analisis $\mathrm{C} / \mathrm{N}$ dari substrat tempat pengambilan sampel. Lazimnya semakin rendah $\mathrm{C} / \mathrm{N}$ substrat dimana eksplorasi dilakukan, mikroba yang diperoleh makin besar. Karena diperkirakan 
proses penguraian telah terjadi. Sehubungan dengan hal tersebut, Kriangsek (1986) mengemukakan bahwa $\mathrm{C} / \mathrm{N}$ rasio merupakan salah satu indikasi yang menunjukkan dimana telah terjadi proses penguraian suatu bahan organik. Akan tetapi dari hasil yang diperoleh ternyata tidak ada indikasi kecenderungan yang menunjukkan jumlah mikroba berdasarkan $\mathrm{C} / \mathrm{N}$ dari substrat baik golongan fungi maupun bakteri. Pada lokasi PT. TEL nilai C/N substrat/tumpukan tertinggi terjadi pada lokasi dengan kode SBM dengan nilai C/N 58, diikuti berturut-turut oleh lokasi dengan kode LFK dan TP4 masing-masing mempunyai nilai $\mathrm{C} / \mathrm{N} 46$ dan 42. Hal yang sama juga dijumpai pada lokasi ke dua yaitu di PT. IKPP. Keduanya sama menunjukkan bahwa pada kondisi $\mathrm{C} / \mathrm{N}$ berapapun bakteri yang diperoleh lebih banyak dari fungi. Hal ini mungkin disebabkan karena eksplorasi dilakukan pada waktu musim kemarau, sehingga fungi sedikit dijumpai. Kalaupun ada, tetapi fungi tersebut tidak terdeteksi karena keberadaannya mungkin dalam bentuk spora.

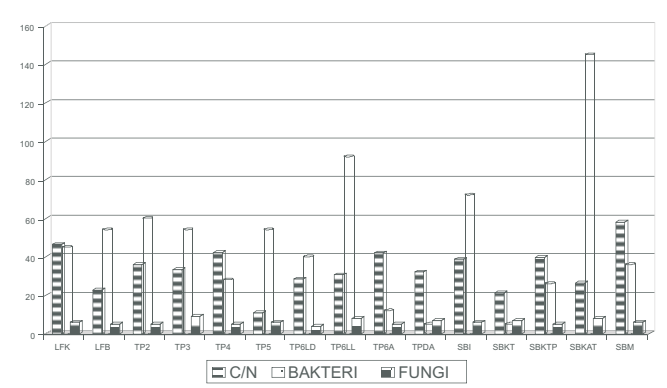

A

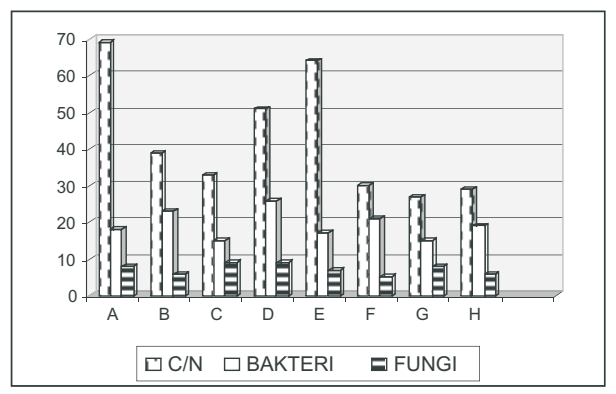

$\mathrm{B}$

Gambar 2. Grafik hasil isolasi mikroba di lokasi pengambilan contoh (A) : PT. TEL dan (B) : PT. IKPP

Figure 2. Graph illustrating the resulting isolation of microbe at two sampling locations: PT TEL (A) and PT.IKPP(B)

\section{B. Isolasi dan Seleksi}

Berdasarkan pertumbuhan mikroba dari masing-masing isolat yang berasal dari PT. TEL menunjukkan bahwa jumlah fungi yang terhitung berkisar antara (4-9) x $10^{4}$ dan (2-5) x $10^{6}$. hal yang sama juga terlihat pada pertumbuhan mikroba asal IKPP yaitu berkisar antara (5-9) $\mathrm{x}$ $10^{4}$ sampai (3-6) x 106 . Pertumbuhan bakteri lebih banyak dijumpai pada intensitas pengenceran $10^{8}$, sedangkan pertumbuhan fungi banyak dijumpai pada intensitas pengenceran $10^{4}$. Isolasi dilakukan berdasarkan intensitas pengenceran, bertujuan agar sel-sel mikroba lebih terpisah satu dengan yang lainnya, sehingga lebih mudah untuk melakukan isolasi (Ruel and Barnoud, 1985; Away dan Goenadi, 1995). Selain itu hasil yang diperoleh melalui cara pengenceran lebih meyakinkan, terutama dalam hal kemurniannya. Pada Tabel 3 dan 4 dapat dilihat hasil isolasi dan seleksi mikroba dari 2 lokasi yaitu PT. TEL dan PT. IKPP dan masing-masing mencakup beberapa lokasi pengambilan contoh. 
Tabel3. Hasil isolasi dan seleksi mikroba asal PT. TEL Palembang berdasarkan lokasi eksplorasi

Table 3. Results of isolation and selection of microbe from PT TEL (South Sumatera) that correspond to exploration location

\begin{tabular}{|c|c|c|c|c|c|}
\hline \multirow[t]{2}{*}{ No } & \multirow[t]{2}{*}{$\begin{array}{l}\text { Kode contoh } \\
\text { (Sample code) }\end{array}$} & \multicolumn{2}{|c|}{$\begin{array}{c}\text { Jumlah bakteri/ } \\
\text { pada pengenceran } \\
\text { (Number of bacteria at dilution } \\
\text { intensity) }\end{array}$} & \multicolumn{2}{|c|}{$\begin{array}{c}\text { Jumlah fungi/ } \\
\text { pada pengenceran } \\
\text { (Number of fungi at dilution } \\
\text { intensity) }\end{array}$} \\
\hline & & $10^{6}$ & $10^{8}$ & $10^{4}$ & $10^{6}$ \\
\hline 1 & LFK & 45 & 13 & 6 & 2 \\
\hline 2 & LFB & 54 & 5 & 5 & 2 \\
\hline 3 & TP2 & 60 & 5 & 5 & 3 \\
\hline 4 & TP3 & 54 & 5 & 9 & 4 \\
\hline 5 & TP4 & TBUD & 28 & 5 & 2 \\
\hline 6 & TP5 & 54 & 5 & 6 & 3 \\
\hline 7 & TP6A & 40 & 43 & 4 & 3 \\
\hline 8 & TP6LL & TBUD & 92 & 8 & 5 \\
\hline 9 & TP6LD & TBUD & 12 & 5 & 2 \\
\hline 10 & TPDA & TBUD & 5 & 7 & 3 \\
\hline 11 & SB1 & 72 & TBUD & 6 & 4 \\
\hline 12 & SBKT & TBUD & 5 & 7 & 3 \\
\hline 13 & SBKTB & TBUD & 26 & 5 & 3 \\
\hline 14 & SBKAT & TBUD & 145 & 8 & 5 \\
\hline 15 & SBM & TBUD & 36 & 6 & 4 \\
\hline
\end{tabular}

Keterangan (Remarks): TBUD = Tidak bisa untuk dihitung (uncountable)

Tabel4. Hasil Isolasi dan seleksi mikroba asal PT. IKPP Perawang (Riau) berdasarkan lokasi eksplorasi

Table 4. Results of isolation and selection of microbe from PT IKPP Perawang (Riau) that corresponded to exploration location

\begin{tabular}{|c|c|c|c|c|c|}
\hline \multirow{2}{*}{ No } & \multirow{2}{*}{$\begin{array}{c}\text { Kode contoh } \\
\text { (sample code) }\end{array}$} & \multicolumn{2}{|c|}{$\begin{array}{c}\text { Jumlah bakteri } \\
\text { (Number of bacteria) }\end{array}$} & \multicolumn{2}{c|}{$\begin{array}{c}\text { Jumlah fungi } \\
\text { (Number of fungi) }\end{array}$} \\
\cline { 3 - 6 } & & $10^{6}$ & $10^{8}$ & $10^{4}$ & $10^{6}$ \\
\hline 1 & $\mathrm{~A}$ & 63 & 18 & 8 & 4 \\
\hline 2 & $\mathrm{~B}$ & TBUD & 23 & 6 & 4 \\
\hline 3 & $\mathrm{C}$ & TBUD & 15 & 9 & 6 \\
\hline 4 & $\mathrm{D}$ & 57 & 26 & 9 & 5 \\
\hline 5 & $\mathrm{E}$ & 52 & 17 & 7 & 4 \\
\hline 6 & $\mathrm{~F}$ & TBUD & 21 & 5 & 2 \\
\hline 7 & $\mathrm{G}$ & 49 & 15 & 8 & 5 \\
\hline 8 & $\mathrm{H}$ & 59 & 19 & 6 & 3 \\
\hline
\end{tabular}

Keterangan (Remarks) : TBUD = Tidak bisa untuk dihitung (uncountable) 
Beberapa faktor yang mempengaruhi pertumbuhan mikroba terutama adalah komponen dari medium biakan seperti: $\mathrm{pH}$, aktivitas air, dan tekanan osmose, serta beberapa faktor yang berasal dari luar seperti suhu, oksigen dan tekanan (Handrech and Black, 1984). Kesemua ini akan mempengaruhi laju pertumbuhan mikroba. Sedangkan di alam umumnya siklus kehidupan mikroba baik fungi maupun bakteri tergantung dari objek yang ada untuk dirombak Adakalanya degradasi atau perombakan diawali oleh mikroba golongan fungi, setelah terjadi proses degradasi dalam kurun waktu tertentu, fungi akan mati tetapi tersimpan dalam bentuk spora untuk selanjutnya degradasi tersebut dilanjutkan oleh bakteri, atau bisa sebaliknya yaitu degradasi diawali oleh bakteri untuk selanjutnya diteruskan oleh fungi. Kondisi seperti inilah yang mungkin terjadi pada penelitian ini. Dikarenakan oleh musim kemarau, sehingga jumlah fungi yang diperoleh sedikit. Dalam hal ini bakteri hanya berfungsi sebagai pembusuk, sementara fungi berfungsi sebagai pengurai/dekomposer. Oleh sebab itu fokus pencarian mikroba pada penelitian ini adalah mikroba yang berfungsi sebagai pengurai (Higuchi, 1985).

Telah diketahui bahwa mikroba yang efektif sebagai pengurai pada bahan berkayu (yang mengandung lignin) adalah fungi yang termasuk ke dalam kelas Basidiomycetes, atau lebih terkenal dengan white rot fungi atau fungi pelapuk putih/FPP (Blanchette, et al. 1988). Fungi ini termasuk fungi tingkat tinggi dan mudah dikenal apabila ditemukan tubuh buahnya. Pada bagian bawah tubuh buah biasanya terdapat spora sebagai alat untuk perbanyak diri. Namun beberapa peneliti mengemukakan bahwa hampir tidak pernah menemukan tubuh buah dari fungi ini. Bahkan beberapa peneliti berulang kali mencoba berusaha menumbuhkan tubuh buah dari fungi ini, tetapi hingga sekarang belum berhasil. Oleh sebab itu fungi yang termasuk FPP ini bukan mikroba yang menjadi target penelitian, karena tidak dapat digunakan sebagai bahan utama untuk dikemas sebagai aktivator. Hal ini disebabkan karena sulit menemukan sporanya. Sehingga yang menjadi target pencarian adalah fungi tingkat rendah. Di alam fungi ini mudah dijumpai melalui warna dari spora. Berbagai warna dapat dijumpai mulai warna kemerahan, kekuningan, hijau atau putih.

Berdasarkan hasil pengamatan serta dari beberapa ciri, acuan serta informasi yang diperoleh, sebagaian besar fungi yang didapatkan termasuk FPP dan untuk sementara diperkirakan genus Tricoderma. Diketahui bahwa jenis fungi ini adalah salah satu fungi tingkat rendah yang telah banyak digunakan untuk berbagai keperluan (Kirk and Shimada.1984; Away dan Goenadi, 1995), namun belum dapat diketahui spesiesnya. Karena untuk menentukan spesies suatu mikroba, membutuhkan waktu yang relatif lama dengan biaya yang tinggi. Sehingga untuk sementara pencarian spesies dari genus Tricoderma tersebut ditunda, namun lebih difokuskan pada efektivitas dari mikroba tersebut, melalui tahapan pengujian baik secara invitro, laboratorium, maupun skala lapangan. Jika hasil yang diperoleh sudah dapat diyakini maka, selanjutnya baru dilakukan pencarian spesies. Pengujian selanjutnya hanya dilakukan terhadap isolat fungi, karena isolat inilah yang menunjukkan aktivitas pengurai. Isolat bakteri yang diperoleh hanya bersifat pembusuk, sehingga untuk sementara tidak dilakukan pengujian lanjutan, tetapi akan disimpan dalam kultur pada kondisi yang sesuai, sehingga bila dibutuhkan bahan tersedia untuk dipelajari. 


\section{Uji Selulolitik}

Hasil pengamatan menunjukkan bahwa, hampir semua isolat fungi positif mempunyai kemampuan menguraikan selulosa dengan kecepatan sedang hingga cepat. Hal ini ditandai dengan penampakan luas cincin yang lebih besar dari $5 \mathrm{~cm}$ pada suhu $28^{\circ} \mathrm{C}$ dan 37 ${ }^{\circ} \mathrm{C}$. Isolat fungi tersebut umumnya melepaskan $\mathrm{RBB}$, menghilangkan $\mathrm{RBB}$, dan sekaligus menghilangkan dan melepaskan RBB.

Menurut Basuki (1994), penggunaan senyawa RBB dilakukan karena molekul pewarna tersebut akan membentuk ikatan kovalen dengan unit molekul glukosa dari beberapa jenis polisakharida termasuk diantaranya selulosa. Fungi yang mempunyai kemampuan selulolitik apabila dikulturkan pada selulosa yang diberi pewarna RBB akan menghidrolisis selulosa dan melepas glukosa. Warna biru pada media disebabkan oleh pewarna RBB yang berwarna biru berikatan dengan molekul-molekul glukosa. Selanjutnya dijelaskan juga bahwa fenomena yang mungkin terjadi dalam pengujian ini antara lain: (a) isolat mendegradasi selulosa dari selopan sehingga pada media terjadi pelepasan warna biru, dan media akan berwarna biru, atau (b) isolat merombak pewarna RBB pada selopan sehingga warna biru dari selopan hilang dan selopan menjadi berwarna putih, atau (c) isolat mendegradasi selulosa dari selopan dan juga merombak pewarna RBB (Gambar 2).

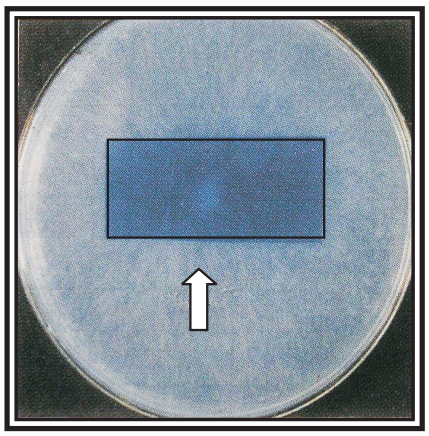

a

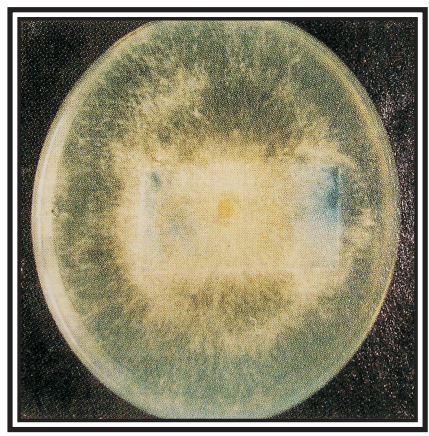

$\mathrm{b}$

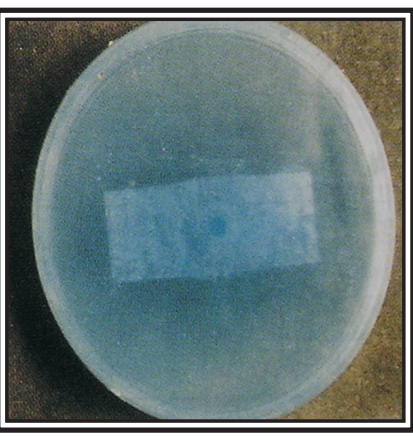

$\mathrm{C}$

Gambar 3. Uji selulolitik dari salah satu isolat, (a) pelepasan $\mathrm{RBB}$, (b) penghilangan RBB, dan (c) pelepasan dan penghilangan RBB

Figure 3. Cellulolitic test on one of the isolats (a) the release of $R B B$; (b) the disappearance of $R B B$; and (c) the release and disappearance of $R B B$

Pada penelitian ini uji selulolitik hanya digunakan sebagai uji penunjang, karena fokus penelitian adalah uji lignolitik. Hal ini didasari oleh tujuan dan sasaran secara keseluruhan dari penelitian, bahwa semua teknik dan metode yang dikerjakan adalah untuk memperoleh mikroba potensial dan efektif yang selanjutnya akan dikemas menjadi suatu produk aktivator pengomposan pada limbah kulit kayu. Oleh sebab itu uji selulolitik digunakan sebagai uji dasar untuk menunjang uji selanjutnya. Selain itu uji selulolitik seringkali digunakan pada kegiatan yang bertujuan pencarian mikroba pengurai bahan lignoselulosa, yang mempunyai 
potensi memisahkan lignin dengan selulosa atau hemiselulosa tanpa merusak selulosa maupun hemiselulosa. Meskipun banyak hasil penelitian terdahulu menunjukkan bahwa beberapa mikroba tertentu dapat memisahkan lignin, tetapi masih tetap merusak selulosa walaupun dalam jumlah sedikit. Ciri ini umumnya dijumpai pada FPP, sehingga berpotensi digunakan dalam industri, terutama industri pulp kertas yang diolah secara biokimia-mekanis, yang selama ini dilakukan secara kimia (Blanchette et al. 1988; Kirk dan Erikson, 1989; Away dan Goenadi, 1995). Sementara mikroba target untuk aktivator tidak membutuhkan sifat selektif dalam penguraian seperti FPP tersebut. Sifat yang dibutuhkan dapat menguraikan lignin yang efektif tanpa memperdulikan keadaan selulosa, ini disebabkan karena dalam proses lignolitik, selulosa dengan sendirinya akan ikut terurai bersamaan dengan penguraian lignin.

\section{Uji Lignolitik}

Untuk mengetahui isolat dalam menguraikan lignin, dilakukan pengujian mengikuti metode Nishida et al. (1988) yang dimodifikasi. Bubuk kulit kayu mangium sebagai sumber lignin dihaluskan hingga 150 mesh. Area cincin cokelat yang terbentuk di sekitar koloni menunjukkan adanya kemampuan penguraian lignin. Gambar uji lignolitik dari salah satu isolat dapat dilihat pada Gambar 3. Parameter yang diamati pada hari ke tujuh adalah intensitas warna cokelat dari daerah cincin antara terang, sedang, atau gelap, kemudian diukur luasnya. Selanjutnya untuk menentukan isolat terpilih, yaitu yang dapat membentuk area cincin cokelat dengan intensitas warna gelap dengan luas yang melebihi $5,0 \mathrm{~cm}^{2}$. Berdasarkan pengamatan dari luas area cincin cokelat yang lebih dari $5 \mathrm{~cm}^{2}$, terpilih 7 isolat fungi yang diperkirakan potensial efektif mewakili kedua lokasi (PT. TEL Pulp dan Paper dan PT. IKPP).

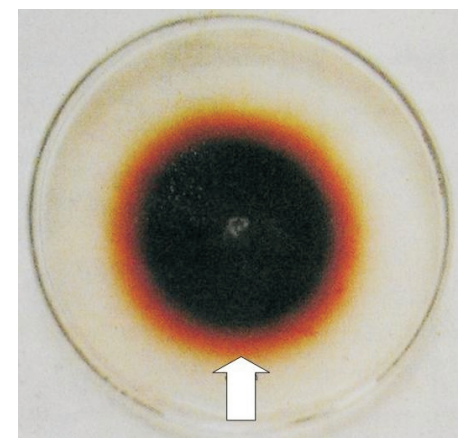

Gambar 4. Uji lignolitik dari salah satu isolat (tanda panah menunjukkan lingkaran area cincin cokelat sebagai indikasi perkiraan isolat potensial yang efektif)

Figure 4. Lignolitic tests on one at the isolats (arrow designates area circle that reveals brown colored ring as indication of isolats presumed potentially effective) 
Beberapa sumber menyebutkan bahwa kandungan lignin yang terdapat pada kulit kayu mangium digunakan oleh isolat sebagai sumber karbon untuk memperoleh energi melalui proses enzimatik. Aktivitas enzim pengurai lignin dari isolat menyebabkan polimer ini mengalami depolimerisasi menjadi beberapa komponen penyusun lignin yang berwarna cokelat dengan intensitas warna dan luas yang berbeda pada media (Kirk, 1985; Away dan Goenadi, 1995).

\section{KESIMPULAN DAN SARAN}

\section{A. Kesimpulan}

1. Dari dua lokasi eksplorasi yang telah dilakukan, diperoleh 46 isolat mikroba yang terdiri dari 23 isolat fungi dan 23 isolat bakteri. Sebanyak 30 isolat (15 isolat fungi dan 15 isolat bakteri) asal PT. TEL (Sumatera selatan), dan 16 isolat (8 isolat fungi \& 8 isolat bakteri) asal PT. IKPP, Perawang (Riau).

2. Hampir semua isolat fungi positif mempunyai kemampuan menguraikan lignin dan selulosa dengan kecepatan sedang hingga cepat, sedangkan isolat bakteri yang diperoleh ternyata hanya bersifat pembusuk.

3. Diantara semua isolat yang diperoleh, terpilih 7 isolat fungi yang diperkirakan potensial efektif mewakili ke dua lokasi.

\section{B. Saran}

Perlu diuji efektivitas 7 isolat potensial yang diperkirakan efektif sebagai dekomposer baik secara in vitro maupun skala laboratorium

\section{DAFTAR PUSTAKA}

Away, Yufnal dan Goenadi, D. H., 1995. Isolasi dan seleksi fungi pelapuk putih dari tandan kosong kelapa sawit. Menara Perkebunan. Jurnal Penelitian Bioteknologi Perkebunan. Tahun ke 63 No.3. Pusat Penelitian Bioteknologi Perkebunan. Bogor.

-, 1995. Pemanfaatan fungi pelapuk putih sebagai activator delignifikasi tandan kosong kelapa sawit dalam proses pembuatan pulp secara biokemis. Laporan Tahunan 1995 Pusat Penelitian Bioteknologi Perkebunan. Asosiasi Penelitian dan Pengembangan Perkebunan Indonesia. Bogor.

Basuki, T. 1994. Biopulping, biobleaching dan biodegradasi limbah industri pulp kertas oleh jamur Basidiomycetes Phanerochaete chrysosporium. Laporan Penelitian PAU. Bioteknologi. Institut Teknologi Bandung, Bandung.

Blanchette, R.A. dan T.A. Burnes, G.F. Leatham dan M.J. Effland (1988). Selection of white rot fungi for biopulping. Biomass, 15, 93-101.

Brundrett M, N. Bougher, B. Dell, T. Grove, and Malajczuk. 1996. Working with mycorrhizas in forestry and agriculture. ACIAR Monograph $32.374+\mathrm{x}$. 
Flechter, A. 1986. Biodegradation of lignocellulosic materials. Microbial utilization of renewable resources. Vol. 5. Joint Seminar on Biotechnology, Osaka Japan, p. 283-290.

Gusmailina, S. Komarayati, G. Pari, dan D. Hendra. 2002. Kajian teknologi pengolahan arang dan limbah pengolahan pulp dan kertas di Sumatera Selatan. Prosiding Seminar Hasil Penelitian Teknologi Hasil Hutan. Bogor.

Hadiutomo, R. S. 1988. Metode metode untuk bakteriologi. PAU-IPB bekerjasama dengan Lembaga Sumberdaya Informasi-IPB. Bogor.

Handrech KA. and N.D. Black. 1984. Growing Media for Ornamental Plants and Turf. New South Wales University Press, Sydney.

Higuchi, T. 1985. Biosynthesis and Biodegradation of Wood Components. Academic Press, Inc. New York.

Judoamidjojo, R.M., E.G. Said dan L. Hartarto (1989). Biokonversi. PAU Bioteknologi, Institut Pertanian Bogor, Bogor.

Kirk, T. K. 1985. Lignin Biodegradation: the Microorganism Involved and Physiology and Biochemistry of Degradation by White-Rot Fungi. In Higuchi, T (ed). Biosynthesis and Biodegradation of wood Component. Academic Press, Inc., Orlando.

Kirk, T.K. dan K.E. Erikson (1989). Roles for biotechnology in manufacture. In Robert Frank (Ed). Worl pulp and paper technology 1990 - The international review for the pulp and paper industry. P. 23-29. London, Sterling publishing group PLC.

Kirk, T.K. and M. Shimada. 1984. Lignin Biodegradation: the Micro organisme Involved and the Physiology and Biochemistry of Degradation by White Rot Fungi. Academic Press, Inc. New York.

Kuntoro, S. (1985) Mikroba dan Hari Depan Manusia. Lembaga Penerbitan Yayasan Padamu Negeri. Jakarta.

Kriangsek, M.U. , 1986. The Use of Chemical and Organic Fertilizer Rice-Fish Culture System. Unpublished MS Thesis. CLSU. Munos. Nueva Ecija. Philippines.

Moore, R.L., B.B. Basset dan M.J. Swit. 1979. Developments in the remazol brilliant blue dyeassay for studying the ecology of cellulose decomposition. Soil Biology and Biochemistry, 11:311-312.

Nishida, T., Y. Kashino, A. Mimura dan Y. Takahara. 1988. Lignin biodegradation by woodrooting fungi. I. Screening oflignin degrading fungi. Mokuzai Gakkaishi, 34:530-536. Japan.

Panshin, A. J. Dan C. De Zeeuw. 1978. Textbook of Wood Technology 3rd ed. McGraw-Hill Book Company. New York.

Poincelot, R.P. dan P.R. Day. 1972. Simple dye release assay for determining cellulolitic activity of fungi. Appl. Microbiol. 23:875-879. 
Rao, N.S Subha, 1994. Mikroorganisme Tanah dan Pertumbuhan Tanaman. Edisi Kedua. Penerbit Universitas Indonesia.

Rayner, A.D.M. dan L.I.Body. 1988. Fungal Decomposition of Wood.Its Biology and Ecology. John Wiley dan Sons. Nath Avon.557p.

Ruel, K dan F. Barnoud. 1985. Degradaton of Wood by Microorganisms. In T. Higuchi (ed). Byosynthetic and Biodefradation Wood Component. Academic Press, New York.

Soltes, J. 1983. Cellulose: Elusive Component of the Plant Cell Wall. In W.A. Cote (Ed). Biomass Utilization, p. 283-290. New York, Plenum Press. 